\title{
The Scientific Views about Understanding the Child
}

\section{Уявлення науковців про розуміння дитини}

Natalia Tsybuliak

Ph.D. in Psychology,

Assistant Professor
Наталя Цибуляк

кандидат психологічних

наук, доцент

\section{e-mail: nata.tsibulyak@gmail.com orcid.org/0000-0003-2474-8614 \\ Researcher ID: O-8734-2017 Scopus Author ID: 57200150887}

Berdiansk State Pedagogical University, Berdiansk, Ukraine

4, Shmidta str., Berdiansk, Zaporizhzhia region, 71100

Hanna Lopatina Ph.D. in Pedagogy, Assistant Professor
Бердянський державний педагогічний університет, м. Бердянськ, Україна вул. Шмідта, 4, м. Бердянськ, Запорізька область, 71100

\section{Ганна Лопатіна}

кандидат педагогічних наук, доцент

$$
\begin{gathered}
\text { e-mail: lopatina.hanna29@gmail.com } \\
\text { orcid.org/0000-0002-3920-6853 } \\
\text { Researcher ID: W-1713-2018 } \\
\text { Scopus Author ID: 57200145628 }
\end{gathered}
$$

Berdiansk State Pedagogical University, Berdiansk, Ukraine

4, Shmidta str., Berdiansk, Zaporizhzhia region, 71100
Бердянський державний педагогічний університет,

м. Бердянськ, Україна вул. Шмідта, 4, м. Бердянськ, Запорізька область, 71100

Original manuscript received December 26, 2018 Revised manuscript accepted February 02, 2019 


\section{ABSTRACT}

The article considers the scientific-psychological approaches of the concept of "understanding": psychological hermeneutics, cognitive, logical semantic, psychosemantic, psycholinguistic, subjective, and communicative. It was proved that the interpretation of understanding as a process of reveal the meaning and content of a particular phenomenon was common for the beforementioned approaches. That is accompanied with a person's confidence in the accuracy of own conclusions and due to the action of a number of factors that affect the adequacy, completeness and depth of the information received. The preschool teacher's understanding of a child's personality is considered in three directions: as a goal, as a process, as a result. These directions are interdependent. It is emphasized the complexity of understanding as a process, caused by the influence of a number of objective and subjective factors.

The authors of the article consider the types of understanding of the individual characteristics of the child by the preschool teacher. It is proved that the optimal interaction between the educator and the children is the position of the understanding-dialogue, in which the adult not only treats the child as a kind of complex individual characteristics with a rich inner world, but also gives the feedback. This creates trust and support, and facilitates to reveal the capacity of the child.

It was described a lot of subjective factors influencing the understanding of the child's personality by the preschool teacher. Some of the subjective factors are established to influence the process of understanding both positively and negatively.

The results having been received in this research proved that the subjectsubject type of understanding is the best for pedagogical activity. This type of understanding provides that the preschool teacher seeks to reveal adequately the individual characteristics of the child, admits her or his uniqueness, supports in every possible way the efforts aimed at her or his self-affirmation, self-realization, self-expression and self-development.

Key words: understanding, stages of understanding, types of understanding of the child's personality by preschool teacher, subjective factors of understanding.

\section{Вступ}

Проблема розуміння є однією з центральних проблем не лише у психології та педагогіці, а й в усіх гуманітарних науках. Це пов'язано, передусім, із тим, що сучасне суспільство перебуває в постійному пошуку сприятливих 
умов для гармонійного становлення особистості. Дошкільна освіта - це перша освітня ланка, від якої залежить не тільки рівень освіченості та вихованості майбутнього покоління, а закладається фундамент психологічного здоров'я i благополуччя. Тому проблема розуміння особистості дитини, без перебільшення, є однією з ключових у діяльності педагога, для якого позиція «разом із дитиною», а не «над дитиною» $є$ визначальною.

Проблема розуміння особистості дитини дорослими (зокрема, педагогом) знайшла відображення у низці вітчизняних і зарубіжних психолого-педагогічних досліджень (Ананьєв, 2011; Бех, 2008; Бодальов, 1982; Знаков, 2005; Коваленко, 1999; Кондратьєва, 1980; Савчин, 1996; Liu, Gelman \& Wellman, 2007; Dobbs \& Arnold, 2009; TrawickSmith \& Dziurgot, 2011 та ін.). Разом із тим, учені (Клипа, 1994; Кулачківська, 2005; Кузьменко, 2015; Ладивір, 2005; Піроженко, 2016; Цибуляк, 2015 та ін.) відзначають певні труднощі, що виникають через неадекватне оцінювання та неправильне розуміння вихователями індивідуальних особливостей дитини. Така ситуація є неприпустимою та зумовлює необхідність наукового пошуку їі розв' язання.

Завдання статті - здійснити теоретико-методологічний аналіз підходів до вивчення проблеми розуміння дитини в науковій літературі та визначити стан її розробки.

\section{Методи дослідження}

У дослідженні для аналізу науково-дослідницьких джерел використано теоретичні методи. Це дало змогу: з' ясувати поняттєво-термінологічне поле розуміння та його теоретико-методологічну базу; розкрити типи розуміння дорослим дитини; синтезувати виявлені особливості розуміння дитини; узагальнити виокремлені суб'єктивні чинники, що впливають на розуміння вихователем особистості дитини; обгрунтувати висновки за результатами проведеного дослідження; окреслити перспективи подальших наукових розвідок. 


\section{Результати та дискусії}

Поняття «розуміння» $\mathrm{e}$ складним i неоднозначним через відсутність у науковій літературі його загальноприйнятого визначення. У психологічній науці сутність розуміння розкривається залежно від наукового підходу, в межах якого воно досліджується. Так, психологічна герменевтика (Брудний, 2005; Корет, 1998; Чепелєва, 2009; Шлейєрмахер, 2004 та ін.) визначає розуміння як процедуру тлумачення суб'єктивних станів людини. 3 такої позиції розуміння - це система взаємопов'язаних способів дій i операцій щодо інтерпретації складної психічної реальності людини та їі особистого досвіду. Інтерпретація є правильною, або «справжньою», тоді, коли їі зміст узгоджується та резонує з полем переживань і проблем людини. Результатом такої інтерпретації є цілісне творче розуміння людини, яке об’єднує її емоційну та когнітивну сфери. Це, у свою чергу, стає основою формування нових знань, необхідних для саморозуміння.

Із позиції когнітивного підходу (Келлі, 2000; Harvey, 1961; Schroder, 1961 та ін.) розуміння інтерпретується як невід'ємна складова пізнавальної діяльності людини, під час якої відбувається формування ментальних репрезентацій об'єкта розуміння, тобто знакового або символічного представлення світу. 3 цієї позиції розуміння визначається як універсальна характеристика інтелектуальної діяль-

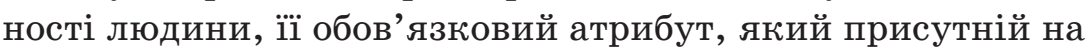
всіх етапах розумового процесу та виступає у різних формах (осмислення проблеми, проблемної ситуації, способів їі вирішення тощо).

Розуміння як здатність до логічних висновків є предметом вивчення у межах логіко-семантичного підходу (Карнап, 2007; Russell, 2009; Tarski, 1944 та ін.), за якого процеси логічного висновку розглядаються як обов'язкові складові розуміння. Людина як носій знакових систем, сформованих на основі минулого досвіду, здійснює розуміння двома основними способами. Так, у разі неповноти 
інформації, що міститься у повідомленні, вона виводиться 3 фрейму, тобто смислового навантаження ситуації. Отримана таким чином інформація співвідноситься зі змістом повідомлення. У тому випадку, коли наявні дані не можуть бути організовані в смислову структуру, для їх інтерпретації залучається минулий досвід. На цій основі будується смислова структура вищого порядку. Основними сполучними ланками між вхідними повідомленнями та сформованими знаннями людини про навколишній світ є умовисновки.

У межах психосемантичного підходу (Дробот, 2016; Петренко, 1983; Серкін, 2004; Шмельов, 1983 та ін.) основна увага зосереджена на проблемі конструювання людиною семантичного уявлення про об'єкт розуміння (значень), тобто аналізу відношення між знаком (словом) і його змістом. Основна увага акцентується на суб'єктивній формі існування значень в індивідуальній свідомості (образи, символи, символічні дії, а також знакові, вербальні форми тощо). Психосемантичний підхід дає змогу визначити два способи категоризації досвіду - інваріантний та індивідуальний. В останньому випадку реконструюється індивідуальний семантичний простір значень та особистісних смислів. Процес розуміння пов'язується з їх взаємопроникненням і взаємодією ("осмислення значень» $\mathrm{i}$ «позначення смислів»). Як зазначав Л. Виготський, процес говоріння вимагає переходу з внутрішнього плану в зовнішній, а розуміння передбачає зворотний рух - від зовнішнього плану мови до внутрішнього (Виготський, 2015).

Психолінгвістика (Белянін, 2009; Засєкіна, 2007; Горелов, 2007 та ін.) вивчає взаємозв'язок розуміння і процесів перетворення структур мови. Розуміння розглядається як результат трансформації поверхневої структури речення в глибинну репрезентацію, що має певний смисловий характер. При цьому на інтерпретацію впливає актуалізований досвід людини, ïi знання, комунікативний намір, параметри ситуації спілкування, у якій здійснюється розуміння, 
тощо. Перетворення текстової інформації - це процес перекладу мовних значень у форму суб'єктивних смислових утворень. У такому випадку інтерпретація набуває яскраво вираженого суб'єктивного характеру.

У межах суб'єктного підходу (Абульханова-Славська, 1994; Знаков, 2005; Татенко, 2012 та ін.) особлива увага приділяється вивченню особистісних механізмів розуміння як проявів «особистісного мислення», а предметом дослідження стає інтерпретація як психологічний механізм вироблення особистісного ставлення до реальної дійсності й уявлення про неї. Цей підхід на перший план виносить вивчення феноменології переживань і ціннісно-смислової позиції суб’єкта, яка має вирішальний вплив на формування смислу фактів, подій, ситуацій тощо.

У комунікативному підході (Бодальов, 1982; З゚уков, 1991; Кузьмина, 1993; Петровська, 1991 та ін.) розглядаються соціально-психологічні аспекти розуміння, а саме механізми, закономірності та стадії цього процесу. У межах цього підходу ключовим поняттям є досягнення взаєморозуміння внаслідок узгодження цілей співрозмовників. Істотне значення для досягнення розуміння партнера по спілкуванню і смислу його повідомлення відіграють довіра та доброзичливість у відносинах між комунікантами. Тому інтерпретація змісту висловлювання людини може істотно змінюватися залежно від того, які цілі їй приписуються.

Представлені підходи до тлумачення поняття «розуміння» не є вичерпними, проте відображають складність цього явища. Спільним для окреслених підходів є визначення розуміння як розкриття смислу та змісту певного явища, що супроводжується впевненістю людини у правильності власних висновків. На характер розуміння впливає низка чинників, що визначають адекватність, повноту та глибину отриманої інформації.

Одним із найцікавіших і, водночас, найбільш складних є розуміння іншої людини: її індивідуальних особливостей, думок, намірів, здібностей, поведінки тощо. Особливо 
гостро ця проблема постає у професійній діяльності педагога, оскільки без глибокого розуміння особистості кожної дитини неможливо усвідомлено й цілеспрямовано забезпечити їі гармонійний розвиток. Відтак, правильне та глибоке розуміння психологічних особливостей дитини, мотивів ïi поведінки дає змогу вибрати адекватну тактику виховання, застосовувати індивідуальний підхід до дитини.

У наукових доробках (Гавриш, 2016; Кондратьєва, 1980; Кулачківська, 2005; Кузьменко, 2015; Ладивір, 2005; Піроженко, 2016 та ін.) проблема розуміння дитини вихователем розглядається у трьох взаємопов'язаних площинах: розуміння як мета, розуміння як результат, розуміння як процес. Так, розуміння як мета діяльності педагога передбачає базис, основу для створення та забезпечення сприятливих умов для особистісного становлення і творчої самореалізації кожної дитини, формування їі життєвої компетентності, а також ціннісного ставлення до людей, самої себе, природи, культури, світу. Вважаємо, що це може розглядатися як віддалена мета, що реалізується у низці ближчих і часткових цілей. Вони крок за кроком ведуть до здійснення цієї основної та водночас віддаленої мети, що висувається на перспективу. Водночас варто підкреслити, що розуміння особистості дитини не може бути самоціллю, а є тим необхідним фундаментом, на якому вибудовується система освітньої роботи з дитиною дошкільного віку.

Розуміння як процес розкриває операційний бік визначення педагогом смислу значення проявів індивідуальних особливостей дітей. Це надзвичайно складне і відповідальне завдання для вихователя. Складність процесу розуміння зумовлена тим, що передбачає взаємодію двох людей, причому різного віку, професії тощо. 3 одного боку, розуміння вихователем індивідуальної своєрідності дитини передбачає проникнення у їі внутрішній світ: пізнавальну діяльність (відчуття, сприймання, пам'ять, увага, мислення, уява тощо); емоційно-вольову сферу (різноманітні почуття, переживання, прояви волі); спонуки до активності 
(потреби, інтереси, переконання, ідеали тощо); психічні утворення (знання, уміння, навички, звички); індивідуально-психологічні властивості (темперамент, характер, здібності); психічні стани (піднесеність, адаптація, схвильованість, афекти, стреси тощо) (Кузьменко, 2015). При цьому педагог повинен зрозуміти ці явища, аналізуючи лише зовнішні прояви дитини, оскільки для фіксації доступно лише те, що малюк виражає ззовні з урахуванням ситуації, контексту, часу та місця взаємодії з ним. Лише в єдності й сукупності ці явища утворюють складну, неповторну та цілісну модель психіки дитини, якій властива особлива динамічність. 3 іншого боку, процес розкриття смислу та значення дій і вчинків дитини, проникнення у їхній зміст залежить від особистості самого вихователя.

Умовно розуміння педагогом особистості дитини у загальному вигляді можна визначити як формування у його свідомості образу малюка через розгортання двох послідовних стадій. Перша стадія - стадія конкретно-чуттєвого відображення. Розуміння - це, насамперед, складна пізнавальна діяльність, що розпочинається з накопичення даних, тобто зі сприймання зовнішніх проявів дитини (міміки, постави, ходи, рухів тощо). Уже на цьому етапі більшість вихователів робить висновки про її особистісні риси, які не виявляються безпосередньо на рівні сприймання. Внутрішній світ дитини розкривається педагогом шляхом пояснення елементів зовнішності, дій, учинків, поведінки та діяльності. На наступній стадії - стадії абстрактно-логічного відображення - вихователь інтерпретує поведінку малюка. Це тривалий і складний розумовий процес, що складається з низки послідовних дій. У функціональному сенсі інтерпретація покликана ліквідувати змістову невизначеність ситуації та виявити приховане значення того, що відбувається. Сутність такої інтерпретації полягає в поєднанні сприйнятих елементів-ознак зовнішності з семантичним змістом. На нього впливає життєвий і професійний досвід педагога, а також наявна система знань. Процес ін- 
терпретації має переважно оцінний характер. Акт оцінки входить у структуру пізнавальних процесів, які результуються в образі-уявленні про дитину, й усвідомлюється як певне враження про неї (Орбан-Лембрик, 2003).

Достатньо складним моментом у процесі розуміння $\mathrm{\epsilon}$ кінцева «розшифровка» мотивів поведінки дитини, що дає змогу оцінювати конкретні вчинки, прогнозувати подальший розвиток особистості, планувати роботу з нею. Як зазначає Л. Орбан-Лембрик, зовнішня інформація (вербальні та невербальні прояви дитини) піддається раціональному і логіко-семантичному аналізу й перегляду. На цьому етапі розуміння педагогом особистості дитини висуваються і перевіряються гіпотези, здогадки, версії того, що відбувається, виявляється новий сенс завдяки зіставленню й аналізу різних даних, виявляються суперечності. Власні версії та думки співвідносяться з думками інших людей, виробляється критичне ставлення до версій i аргументів інших людей, використовується повторна інтерпретація (реінтерпретація) й робиться узагальнення щодо індивідуальних особливостей дитини, прогнозується її подальша поведінка, відбувається планування освітньої роботи (Opбан-Лембрик, 2003).

По суті, кінцевим продуктом процесу розуміння вихователем особистості дитини є такий напрям: розуміння як результат, що в контексті педагогічної діяльності розглядається як отримання об'єктивної, різнобічної, глибокої та професійно значущої інформації про індивідуальні особливості дітей, із якими працює вихователь. Результат завжди взаємопов' язаний із метою та визначає траєкторію подальшої роботи.

Варто зазначити, що у сформованому образі дитини досить часто можуть бути відображені не всі характерні для неї індивідуальні особливості. Це пов' язано з тим, що у зовнішньому прояві внутрішнього світу дитини певні ознаки відображаються виразно, грунтовно, детально й точно, інші - невиразно, помилково, а на деякі педагог сам не 
звертає уваги. У випадку недостатньої фіксації цих зовнішніх проявів індивідуальних особливостей дитини розуміння її особистості часто є схематичним і спрощеним. Окрім того, процес розуміння педагогом також характеризується селективністю (вибірковістю) сприйняття, впливом низки власних індивідуальних особливостей на процес розуміння. Так, результати експериментальних досліджень дають підстави виокремити загальні тенденції розуміння особистості дитини дорослими:

- характеризуючи особистість дитини, спочатку виокремлюються ті якості, що розкривають взаємовідносини дитини з іншими людьми (дорослими й однолітками);

- i вихователі, і батьки досить низько оцінюють такі якості особистості дитини, як «уважність» $\mathrm{i}$ «слухняність», та більш високо - «веселість» і самостійність»;

- дорослі ототожнюють свої уявлення й оцінки особистісних якостей дитини з рефлексивними очікуваннями ( «я думаю про дитину так само, як дитина про себе, я добре її знаю та розумію»). Це призводить до того, що дорослі досить часто застосовують стратегію маніпуляції замість того, щоб ураховувати індивідуальні особливості дитини;

- судження вихователів характеризуються критичністю, мають афективно-дескриптивний чи аргументований оціночно-інтерпретаційний характер, у портреті особистості дитини частіше відображені негативні якості особистості;

- вихователі звертають увагу, насамперед, на ті якості особистості дитини, що репрезентовані в категоріях «пізнавальна сфера» ( «здібна», «розумна», «уважна», «допитлива» тощо) i «поведінка» («турботлива», «добра», «ввічлива», «довірлива» тощо) (Клипа, 1994).

Складність процесу розуміння вихователем особистості дитини зумовлює наявність різних його типів. Так, у процесі педагогічної діяльності М. Савчин умовно виокремлює три основні типи. Перший тип - механічне розуміння психіки й особистості дитини, що випливає зі спрощеного 
розуміння людини взагалі, орієнтації на дуже узагальнені та примітивні закони функціонування психіки. Вона розглядається як пасивний об’єкт і продукт впливу зовнішніх умов, тому вихователь зорієнтований на забезпечення та реалізацію означених умов. Його не цікавлять внутрішні переживання й індивідуальні особливості дитини. У цьому разі має місце не педагогічна взаємодія, а односторонній вплив дорослого на дитину. Цей тип розуміння дитини вихователем можна назвати імперативним. Психологічно такий вплив хоча і призводить до короткочасного підкорення дитини вимогам дорослого, але не пробуджує у неї глибинних переживань, які б викликали якісні особистісні зміни. Тобто, між вихованцем і педагогом майже не виникає ніякого взаєморозуміння.

Другий тип - розуміння дитини як суб’єкта поведінки та діяльності. Цей тип відповідає «суб'єктній» парадигмі в психологічній науці, згідно з якою визнається активність й індивідуальна вибірковість психічного відображення дитиною зовнішніх впливів. Тобто, вона здійснює перетворювальний вплив на інформацію, що надходить ззовні. Специфічною особливістю цього типу розуміння $є$ те, що педагог, констатуючи наявність у дитини індивідуальних особливостей, не визнає за нею права володіти ними. Вихователь продумує, розробляє і застосовує ще більш витончені засоби маніпулювання психікою вихованця, виходячи 3 його індивідуальних відмінностей, але нехтуючи актуальними потребами та нівелюючи потенційні можливості дитини.

Третій тип розуміння дошкільника базується на «суб’єкт-суб'єктній», або "діалогічній», парадигмі, відповідно до якої психіка людини розглядається як відкрита система, наділена зовнішніми та внутрішніми контурами регулювання. Педагог ставиться до дитини як до своєрідної складної індивідуальності з багатим внутрішнім світом, i не тільки визнає за нею право на неповторність, але всіляко підтримує зусилля, спрямовані на самоствердження, само- 
реалізацію, самовираження і саморозвиток. Якщо в основі педагогічного впливу лежить таке розуміння особистості дитини, то він набуває характеру розвивального ( «суб’єктсуб’єктного»). Це, власне, і є педагогічною взаємодією, що забезпечує актуалізацію потенціалів саморозвитку як вихованця, так і вихователя. Психологічною умовою реалізації такого впливу є діалог (Савчин, 1996).

Існує інша класифікація типів розуміння особистості дитини вихователем, запропонована академіком I. Бехом. Перший тип - розуміння як оцінка. Педагог висловлює свою думку щодо дій, учинків, переживань і хвилювань дитини. Тобто, дорослий лише констатує те, що відбувається з дитиною, а в самій оцінці немає критики й осуду. Другий тип - розуміння як інтерпретація. Педагог прагне пояснити дитині, що насправді відбувається з нею, на чому грунтуються її переживання. Третій тип - розуміння як підтримка. Вихователь намагається втішити дитину, заспокоїти їі. Такий педагог шукає аргументи, які б відновили душевну рівновагу дошкільника. Четвертий тип розуміння як пошук. Реакція вихователя у такому випадку - отримати додаткову інформацію. Дорослий хоче більше дізнатися про те, що відбувається, щоб глибше та повніше зрозуміти ситуацію й обговорити їі з дитиною. П'ятий тип - власне розуміння. Педагог показує дошкільнику, що розуміє його проблеми. Вихователь переказує своїми словами те, що зрозумів, уточнює, наскільки правильно сприйнята ситуація загалом, а також пов'язані з цими подіями можливі думки та почуття дитини (Бех, 2008).

Вищезазначені типи розуміння узагальнено відображають основну гаму взаємин, що проявляється у процесі педагогічної діяльності. Оптимальною для взаємодії вихователя з дітьми є позиція власне розуміння, або розуміння-діалогу, за якої дорослий не тільки ставиться до вихованця як до своєрідної складної індивідуальності з багатим внутрішнім світом, а й надає дитині зворотну реакцію. Це створює атмосферу довіри та підтримки, у якій стає мож- 
ливою актуалізація внутрішнього потенціалу дитини, їі гармонійний розвиток. Адже для забезпечення діалогізму у взаємодії з дітыми необхідно навчитися чути іншого, діяти з урахуванням імовірності існування позиції, відмінної від своєї, інших смаків, поглядів тощо (Гавриш, 2009). Ця теза знаходить підтвердження в експериментальних дослідженнях, у яких установлено, що від того, як вихователь розуміє індивідуальні особливості дошкільника, залежить його самосприйняття, тобто дитина дивиться й оцінює себе очима значущих дорослих (Клипа, 1994).

Попри важливість і необхідність діалогічного типу розуміння, або власне розуміння, в професійній діяльності вихователя закладу дошкільної освіти, цей вибір є неусвідомлюваним і залежить від низки об'єктивних і суб'єктивних чинників. До об’єктивних можна віднести ті, що не залежать від педагога, як-от: тривалість, контекст, ситуація, час і місце взаємодії тощо. Суб’єктивні чинники визначаються індивідуальними особливостями самого вихователя. Розглянемо їх детальніше.

1. Стать педагога. Виявлено, що педагоги-жінки $є$ більш спостережливими. Це дає їм змогу проникати у внутрішній світ дитини (Коломинський \& Березовін, 1977). Ж̊інки також повніше та глибше розуміють інтелектуальні, вольові якості та риси характеру, що виражають ставлення дитини до людей і до самих себе (Кондратьєва, 1980). Це пов' язано з особливостями емоційної сфери чоловіків i жінок, деякими відмінностями їх соціальних функцій, комунікативною спрямованістю та зацікавленістю жінок до партнерів по спілкуванню.

2. ЖКиттєвий і професійний досвід вихователя. Виявлена така закономірність - чим ширше коло спілкування педагога, тим краще він розуміє своїх вихованців. Цікавими є результати досліджень Я. Коломинського та Н. Березовіна щодо впливу професійного досвіду на адекватність розуміння дитини. Доведено, що молоді педагоги (зі стажем до п'яти років) адекватніше й глибше розуміють дітей (Ко- 
ломинський \& Березовін, 1977). Очевидно, це пояснюється тим, що у них ще не сформувалися стереотипи, які ускладнюють проникнення у внутрішній світ вихованця. Про це свідчать також дані досліджень С. Кондратьєвої. Загальна кількість ознак особистості дитини, які називає педагог, зменшується в міру збільшення тривалості стажу роботи. Вихователі зі значним стажем надають більш узагальнену характеристику дитині, вони все частіше застосовують глобальні оцінки її особистості. Однак характер цього узагальнення у процесі відображення особистості учня у педагогів зі стажем неоднаковий: педагог-майстер надає творче узагальнене відображення особистості дитини, що полягає у виявленні їі індивідуальної своєрідності; за недостатньої сформованості педагогічної майстерності узагальнення носить стереотипний і формалістичний характер (Кондратьєва, 1980).

2. Знання про вікові особливості психічного розвитку людини в період дитинства. Це передбачає не тільки оволодіння науковою психологією та її методами, але і знання закономірностей процесу проникнення у внутрішній світ дитини, характеру впливу на цей процес конкретних умов і завдань педагогічної діяльності й особливостей особистості самого вихователя.

3. Професійно-педагогічна спрямованість вихователя. Інтерес до внутрішнього світу особистості, яка формується, психологічна допитливість педагога складаються безпосередньо у процесі пізнання дитини. Це породжує протиріччя між висновками, отриманими на основі вивчення особистості, й новими фактами поведінки дитини. Усвідомлення цього протиріччя спонукає педагога до постійного пошуку та розкриття неповторності кожного вихованця.

4. Стиль педагогічної діяльності. Виявлено, що за авторитарного стилю вихователь частіше за все надає аргументовані оціночно-інтерпретаційні характеристики дитині. При цьому ставлення до неї залежить від ставлення педагога до батьків цієї дитини (насамперед, до матері). Характе- 
ристика особистості вихованця ліберального педагога відзначається неаргументованістю суджень і суб’єктивністю оцінок пізнавальних досягнень дитини та ї поведінки. Вихователь із демократичним стилем менш критичний i категоричний, при цьому звертає увагу не тільки на особливості пізнавальної сфери та поведінки дитини, а й на характер її взаємодії з іншими людьми і психоемоційний стан (Клипа, 1994).

5. Високий рівень педагогічної майстерності. Результати низки експериментальних досліджень свідчать, що рівні розуміння особистості дитини співпадають із рівнями педагогічної майстерності (Коломинський \& Березовин, 1977; Кондратьєва, 1980). Установлено, що для педагогамайстра характерно проникнення у потенційні можливості дитини й оптимістичність характеристики її особистості. Також виявлено, що з підвищенням рівня педагогічної майстерності підвищується педагогічна оцінка досягнень дитини, чіткіше виявляється позитивне ставлення до неї, підвищується об'єктивність розуміння індивідуальної своєрідності та неповторності кожної особистості. У своїй роботі педагог-майстер спирається на сильні сторони характеру та здібності дитини. I навпаки - педагогу, який недостатньо володіє педагогічною майстерністю, нерідко властива суб'єктивність розуміння, його залежність від настанов (іноді негативних), стереотипів, упередженості тощо.

Визначено також залежність оцінки особистісних властивостей дитини від її навчальних досягнень. Так, Б. Ананьєв довів, що, характеризуючи дитину з високим рівнем навчальних досягнень, педагог виокремлює, насамперед, iii позитивні якості (зокрема, інтелектуально-вольові); 3 низьким рівнем - відзначає інертність вихованця, його пасивність, загальну нерозвиненість, відсутність здібностей та інтересів; із середнім рівнем - нівелює окремі значущі особистісні якості дитини (Ананьєв, 2011).

6. Розвиненість рефлексії. Для адекватного розуміння дитини вихователю дуже важливо не просто констатувати 
наявні у неї індивідуальні особливості, але й зрозуміти, як вони співвідносяться з його власною діяльністю. Недарма Я. Корчак зазначав, що вихователь переживає болісні хвилини, помічаючи в безпорадності дитини власне безсилля (Корчак, 2014). На думку Н. Гавриш, рефлексія є базовим психологічним механізмом розуміння (Гавриш, 2016). Досить часто педагогу складно пояснити (насамперед, самому собі) причини виникнення тих або інших проблем, проаналізувати свій стиль спілкування та взаємодії з дітьми. Недостатній розвиток рефлексії створює психологічні бар'єри у стосунках із вихованцями, призводить до конфліктів і непорозумінь. У такій атмосфері некомфортно як дітям, так і вихователю. Розвиненість рефлексії сприяє усвідомленню педагогом справжніх мотивів своєї педагогічної діяльності, своїх виховних впливів, допомагає відрізнити власні утруднення та проблеми від чужих, дає змогу застосовувати знання загального характеру до конкретної ситуації, а відтак - більш повно, глибоко, адекватно й об'єктивно розуміти індивідуальність кожної дитини.

\section{Висновки}

Розуміння педагогом особистості дитини - це здатність або процес розкриття смислу та змісту зовнішніх проявів індивідуальних особливостей дитини, що супроводжується впевненістю вихователя у правильності власних висновків щодо причин і наслідків їі поведінки та дій. Оптимальним для педагогічної діяльності є діалогічний тип розуміння, за якого вихователь глибоко й адекватно розкриває індивідуальні особливості дитини, визнаючи за нею право на неповторність, усіляко підтримує зусилля, спрямовані на самоствердження, самореалізацію, самовираження та саморозвиток. На процес розуміння впливає низка чинників, що можуть як позитивно, так і негативно позначатися на розкритті вихователем індивідуальних особливостей дитини. 
Перспективу подальших пошуків у напрямі дослідження вбачаємо у розробці спеціальних психолого-педагогічних технологій, спрямованих на формування у вихователів здатності до адекватного та глибокого розуміння особистості дитини.

\section{Література}

Ананьев Б. Г. Человек как предмет познания. Санкт-Петербург : Питер, 2011. $288 \mathrm{c}$.

Белякова Е. Г. Понимание как категория смыслоориентированной педагогики. Образование и наука. 2006. № 6 (42). С. 21-28.

Бех І. Д. Виховання особистості: підручник. Київ : Либідь, 2008. 848 с.

Бодалев А. А. Восприятие и понимание человека человеком: [моногр.]. Москва : Изд-во Моск. ун-та, 1982.200 с.

Брудный А. А. Психологическая герменевтика. Москва : Лабиринт, 2005. $336 \mathrm{c}$.

Выготский Л. С. Полное собрание сочинений. Т. 2. Москва, 2015. 504 с.

Гавриш Н. Педагогіка розуміння: запитуєте - відповідаємо. Вихователь-методист дошкільного закладу. 2016. № 4. С. 4-8.

Гавриш Н., Лопатіна Г. Пізнавальні діалоги з дошкільниками. Вихователь-методист дошкільного закладу. 2009. № 2. С. 46-52.

Горелов И. Н. Невербальные компоненты коммуникации. Москва : Издво ЛКИ, 2007. 238 с.

Знаков В. В. Психология понимания: проблемы и перспективы. Москва : Ин-т психологии РАН, 2005. 448 с.

Кулачківська С. Є., Гуменюк Г. В., Вовчик-Блакитна О. О., Ладивip С. О., Карабаєва I. І., Піроженко Т. О., Писарєва О. В., Карасьова К. В., Соловйова Л. І. Індивідуалізація виховання в дитячому садку: методичні рекомендації. Київ : Міленіум, 2005. 126 с.

Клыпа О. В. Понимание личности ребенка значимыми взрослыми (родителями и воспитателями) и понимание ребенком себя как личности: автореф. дис. ... канд. психол. наук: спец. 19.00.07 «Педагогическая психология». Москва : РАО, Психол. ин-т., 1994. 21 с.

Коваленко А. Б. Психологія розуміння. Київ : Геопринт, 1999. 184 с.

Коломинский Я. Л. Некоторые педагогические проблемы социальной психологии. Москва : Изд-во «Знание», 1977.64 с.

Кондратьева С. В. Понимание учителем личности учащегося. Вопросы психологии. 1980. № 5. С. 143-148.

Корчак Я. Как любить ребенка. Москва : АСТ, 2014. 480 с.

Кузьменко В., Цибуляк Н. Спостереження - ключ до розуміння дитини. Дошкільне виховання. 2015. № 12. С. 7-13. 
Орбан-Лембрик Л. Е. Соціальна психологія: [навч. посіб. для студ. вищ. навч. закладів]. Київ : Академвидав, 2003. 446 с.

Піроженко Т., Соловйова Л. Психологічний аспект педагогіки розуміння. Вихователь-летодист дошкільного закладу. 2016. № 4. C. 4-8.

Савчин М. В. Типи розуміння вчителем психології учня та їх прояви у педагогічній взаємодії. Рідна школа. 1996. № 1. С. 70-71.

Dobbs, J., \& Arnold, D. (2009) The Relationship Between Preschool Teachers' Reports of Children's Behavior and Their Behavior Toward Those Children. School Psychology, 24 (2), 95-105.

Liu, D., Gelman, S., \& Wellman, H. (2007). Components of young children's trait understanding: Behavior-to-trait inferences and trait-tobehavior predictions. Child Development, 78, 1543-1558.

Trawick-Smith, J., Dziurgot, T. (2011). 'Good-fit' teacher - child play interactions and the subsequent autonomous play of preschool children. Early Childhood Research Quarterly, 26, 110-123.

Tsai, Ch. (2015). Am I Interfering? Preschool Teacher Participation in Children Play. Universal Journal of Educational Research, 3 (12), 1028-1033.

\section{References}

Anan'ev, B. G. (2011). Chelovek kak predmet poznanija [Human as a subject of knowledge]. Sankt-Peterburg Piter [in Russian].

Beljakova, E. G. (2006). Ponimanie kak kategorija smysloorientirovannoj pedagogiki [Understanding as a category of meaning-oriented pedagogy]. Obrazovanie i nauka - Education and science, 6 (42), 21-28 [in Russian].

Bekh, I. D. (2008). Vyhovannia osobystosti [Personality upbringing]. Kyiv : Lybid [in Ukrainian].

Bodalev, A. A. (1982). Vosprijatie i ponimanie cheloveka chelovekom [A human's perception and understanding by a human]. Moskva : Izd-vo Mosk. un-ta [in Russian].

Brudnyj, A. A. (2005). Psihologicheskaja germenevika [Psychological hermeneutics ]. Moskva : Labirint [in Russian].

Vygotskiy, L. S. (2015). Polnoe sobranie sochinenij. T. 2 [Complete collected works ]. (Vol. 2). Moskva [in Russian].

Havrysh, N. (2016). Pedahohika rozuminnia: zapytuiete - vidpovidaiemo [Pedagogy of understanding: asking - we answer]. Vykhovatel-metodyst doshkilnoho zakladu - Educator-methodist of preschool institution, 4, 4-8 [in Ukrainian].

Havrysh, N., \& Lopatina, H. (2009). Piznavalni dialohy z doshkilnykamy [Cognitive dialogues with preschoolers]. Vykhovatel-metodyst doshkilnoho zakladu - Educator-methodist of preschool institution, 2, 46-52 [in Ukrainian]. 
Gorelov, I. N. (2007). Neverbal'nye komponenty kommunikacii [Non-verbal communication components ]. Moskva : Izd-vo LKI [in Russian].

Znakov, V. V. (2005). Psihologija ponimanija: problemy i perspektivy [The psychology of understanding: problems and prospects ]. Moskva : In-t psihologii RAN [in Russian].

Kulachkivska, S. Ye., Humeniuk, H. V., Vovchyk-Blakytna, O. O., Ladyvir, S. O., Karabaieva, I. I., Pirozhenko, T. O., Pysarieva, O. V., Karasiova, K. V., \& Soloviova, L. I. (2005). Indyvidualizatsiia vykhovannia $v$ dytiachomu sadku: metodychni rekomendatsii [Personalization of education in kindergarten: guidelines ]. Kyiv : Milenium [in Ukrainian].

Klypa, O. V. (1994). Ponimanie lichnosti rebenka znachimymi vzroslymi (roditeljami i vospitateljami) i ponimanie rebenkom sebja kak lichnosti [Understanding the child's personality by significant adults (parents and teachers) and the child's understanding of himself as a personality]. Candidate's thesis. Moskva : RAO, Psihol. in-t [in Russian].

Kovalenko, A. B. (1999). Psykholohiia rozuminnia [Psychology of understanding]. Kyiv : Geoprint [in Ukrainian].

Kolominskij, Ja. L., \& Berezovin, N. A. (1997). Nekotorye pedagogicheskie problemy social'noj psihologii [Some pedagogical problems of social psychology]. Moskva : "Znanie» [in Russian].

Kondrat'eva, S. V. (1980). Ponimanie uchitelem lichnosti uchashchegosja [Understanding of the pupil's personality by teacher]. Voprosy psihologii-Questions of psychology, 5, 143-148 [in Russian].

Korchak, Ja. (2014). Kak ljubit' rebenka [How to love a child]. Moskva : AST, 2014 [in Russian].

Kuzmenko, V., \& Tsybuliak, N. (2015). Sposterezhennia - kliuch do rozuminnia dytyny [Observation is the key to understanding the child]. Doshkilne vykhovannia - Preschool education, 12, 7-13 [in Ukrainian].

Orban-Lembryk, L. E. (2003). Sotsialna psykholohiia [Social Psychology]. Kyiv : Akademvydav [in Ukrainian].

Pirozhenko, T. \& Soloviova, L. (2016). Psykholohichnyi aspekt pedahohiky rozuminnia [Psychological aspect of pedagogy of understanding]. Vykhovatel-metodyst doshkilnoho zakladu - Educator-methodist of preschool institution, 4, 4-8 [in Ukrainian].

Savchyn, M. V. (1996). Typy rozuminnia vchytelem psykholohii uchnia ta ikh proiavy u pedahohichnii vzaiemodii [Types of teacher's understanding of pupil's psychology and their demonstration in pedagogical interaction]. Ridna shkola - Native school, 1, 70-71 [in Ukrainian].

Dobbs, J., \& Arnold, D. (2009) The Relationship Between Preschool Teachers' Reports of Children's Behavior and Their Behavior Toward Those Children. School Psychology, 24 (2), 95-105. 
Liu, D., Gelman, S., \& Wellman, H. (2007). Components of young children's trait understanding: Behavior-to-trait inferences and trait-tobehavior predictions. Child Development, 78, 1543-1558.

Trawick-Smith, J., Dziurgot, T. (2011). 'Good-fit' teacher - child play interactions and the subsequent autonomous play of preschool children. Early Childhood Research Quarterly, 26, 110-123.

Tsai, Ch. (2015). Am I Interfering? Preschool Teacher Participation in Children Play. Universal Journal of Educational Research, 3 (12), 1028-1033.

\section{АНОТАЦІЯ}

У статті проаналізовано науково-психологічні підходи до тлумачення сутності поняття “розуміння»: психологічна герменевтика, когнітивний, логіко-семантичний, психосемантичний, психолінгвістичний, суб'єктний, комунікативний. Установлено, що спільним для окреслених підходів є визначення розуміння як процесу розкриття смислу та змісту певного явища, що супроводжується впевненістю людини у правильності власних висновків і зумовлено дією низки чинників, які впливають на адекватність, повноту та глибину отриманої інформації.

Розуміння педагогом особистості дитини розглянуто у трьох напрямках: розуміння як мета, розуміння як процес, розуміння як результат. Визначено їх взаємозалежність $і$ взаємозумовленість. Підкреслено складність розуміння як процесу, що зумовлено дією низки об'єктивних і суб'єктивних чинників. Розглянуто типологію розуміння педагогом індивідуальних особливостей дитини. Установлено, що оптимальним для взаємодії вихователя з дітьми є позиція власне розуміння, або розуміння-діалогу, за якої дорослий не тільки ставиться до вихования як до своєрідної складної індивідуальності з багатим внутрішнім світом, а й надає зворотну реакцію. Це створює атмосферу довіри та підтримки, а також сприяє актуалізації внутрішнього потенціалу дитини. Проаналізовано та схарактеризовано суб'єктивні чинники, що впливають на розуміння вихователем особистості дитини. Установлено, що багато чинників впливають на процес розуміння як позитивно, так і негативно.

Автори дійшли висновку, що оптимальним для педагогічної діяльності є суб'єкт-суб'єктний тип розуміння, за якого вихователь прагне до адекватного розкриття індивідуальних особливостей дитини, визнаючи за нею право на неповторність, усіляко підтримує зусилля, спрямовані на ії самоствердження, самореалізацію, самовираження та саморозвиток. Відтак, існує необхідність розробки психолого-педаго- 
гічних технологій, спрямованих на формування у педагогів здатності до адекватного розуміння особистості дитини.

Ключові слова: розуміння, стадії розуміння, типи розуміння вихователем особистості дитини, суб'єктивні чинники розуміння.

\section{Цыбуляк Наталья, Лопатина Анна. Представления ученых о пони- мании ребенка}

\section{АННОТАЦИЯ}

В статье представлен анализ научно-психологчческих подходов к толкованию сущности понятия "понимание», а именно: психологическая герменевтика, когнитивный, логико-семантический, психосемантический, психолингвистический, субъектный, коммуникативный. Установлено, что общим для данных подходов является определение понимания как процесса раскрытия смысла и содержания определенного явления, которое сопровождается уверенностью человека в правильности собственных выводов, при этом сам прочесс понимания зависит от ряда фракторов, которые влияют на адекватность, полноту и глубину полученной информации.

Понимание педагогом личности ребенка рассмотрено в трех направлениях: понимание как иель, понимание как процесс, понимание как результат. Определены их взаимозависимость и взаимообусловленность. Подчеркнута сложность понимания как прочесса, что обусловлено действием ряда объективных и субъективных факторов. Представлена типология понимания педагогом индивидуальных особенностей ребенка. Установлено, что оптимальным для взаимодействия воспитателя с детьми является позиция "понимание-диалог», при которой взрослый не только относится к ребенку как к своеобразной сложной индивидуальности с богатым внутренним миром, но и предоставляет ему обратную реакцию. Это создает атмосферу доверия и поддержки, а также способствует актуализации внутреннего потенциала ребенка. В статье проанализированы и охарактеризованы субъективные факторы, которые влияют на понимание воспитателем личности ребенка. Определено, что ряд фракторов влияют на процесс понимания как положительно, так и отрицательно.

Авторы пришли к выводу, что оптимальным для педагогчческой деятельности является субъект-субъектный тип понимания, при котором воспитатель стремится к адекватному раскрытию индивидуальных особенностей ребенка, признавая за ним право на непо- 
вторимость, всячески поддерживает усилия, направленные на его самоутверждение, самореализацию, самовыражение и саморазвитие. Следовательно, существует необходимость разработки психологопедагогических технологий, направленных на формирование у педагогов способности к адекватному пониманию личности ребенка.

Ключевые слова: понимание, стадии понимания, типы понимания воспитателем личности ребенка, субъективные факторы понимания. 